\title{
Stripper System Performance in the Replacement Tritium
} Facility

by

L. K. Heung

Westinghouse Savannah River Company

Savannah River Site

Aiken, South Carolina 29808

A document prepared for FIFTH TOPICAL MEETING ON TRITIUM TECHNOLOGY IN FISSION, FUSION, AND ISOTOPIC APPLICATIONS at Belgirate, Lake Maggiore from 05/28/95 - 06/03/95.

DOE Contract No. DE-AC09-89SR18035

This paper was prepared in connection with work done under the above contract number with the $U S$. Department of Energy. By acceptance of this paper, the publisher and/or recipient acknowleoges the U. S. Government's right to retain a nonexclusive, royalty-free license in and to any copyright covering this paper, along with the right to reproduce and to authorize others to reproduce all or part of the copyrighted paper. 


\section{DISCLAIMER}

This report was prepared as an account of work sponsored by an agency of the United States Govemment. Neither the United States Government nor any agency thereof, nor any of their employees, makes any warranty, express or implied, or assumes any legal liability or responsibility for the accuracy, completeness, or usefulness of any information, apparatus, product, or process disclosed, or represents that its use would not infringe privately owned rights. Reference herein to any specific commercial product, process, or service by trade name, trademark, manufacturer, or otherwise does not necessarily constitute or imply its endorsement, recommendation, or favoring by the United States Government or any agency thereof. The views and opinions of authors expressed herein do not necessarily state or reflect those of the United States Government or any agency thereof.

This report has been reproduced directly from the best available copy.

Available to DOE and DOE contractors from the Office of Scientific and Technical Information, P. O. Box 62, Oak Ridge, TN 37831; prices available from (615) $576-8401$.

Available to the public from the National Technical Information Service. U. S. Deparment of Commerce, 5285 Port Royal Rd., Springfield. VA 22161 


\section{DISCLAIMER}

Portions of this document may be illegible in electronic image products. Images are produced from the best available original document. 


\title{
STRIPPER SYSTEM PERFORMANCE IN THE REPLACEMENT TRITIUM FACILITY
}

\author{
L. K. Heung \\ Westinghouse Savannah River Company \\ 773-A, Savannah River Site, Aiken, SC 29808, USA
}

\begin{abstract}
The Replacement Tritium Facility (RTF) at the Savannah River Site in the United States was designed and built to handle kilogram levels of tritium. The RTF was started up in January 1994. All the design objectives were achieved. To minimize tritium release to the environment, the tritium handling process is installed inside nitrogen-atmosphere gloveboxes. Any tritium that might leak from the process to the gloveboxes is recovered by stripper systems. The tritium concentration in the gloveboxes is normally maintained at below $0.1 \mathrm{Ci} / \mathrm{m}^{3}$. During a large tritium leak from the process to the glovebox, the stripper system lowered the tritium concentration in the glovebox from about $8,000 \mathrm{Ci} / \mathrm{m}^{3}$ to about $100 \mathrm{Ci} / \mathrm{m}^{3}$ in one hour. After that the tritium concentration decreased very slowly. It required 5 days of stripping before the concentration was down to about $10 \mathrm{Ci} / \mathrm{m}^{3}$.
\end{abstract}

\section{INTRODUCTION}

The RTF was built to handle kilograms of tritium inside gloveboxes. The process has the capability to separate tritium isotopes from other gases, to separate tritium from its isotopes, to load and unload tritium from tritium containers. Its development background and process description have been presented elsewhere ${ }^{1,2}$.

The confinement system in the RTF is designed to minimize tritium release to the environment, and to protect workers from tritium exposure. The system consists of 30 nitrogen filled gloveboxes, 2 primary stripper systems, 1 secondary stripper system, a purge stripper and a zeolite bed recovery system. The gloveboxes enclosing the tritium processing equipment are divided into two 15-glovebox groups. Each group is supported by one of two primary stripper systems under normal operating conditions. The nitrogen is circulated through the stripper system continuously at an average residence time of about 2 hours. In the event of an accidental tritium release in a particular glovebox, the nitrogen in that glovebox will be diverted to circulate through the secondary stripper system which reduces the residence time to about 8 minutes. In this way the tritium can be stripped quickly and the affected glovebox does not contaminate the other gloveboxes with high 
concentration tritium. The glovebox is returned to the primary system after the tritium level is reduced to the normal level.

To control the oxygen level in the gloveboxes, a side stream is taken from the outlet side of the primary stripper systems and sent to the purge stripper. The purge stripper serves as a third barrier which ensures that the tritium concentration in the purge nitrogen is below $0.01 \mathrm{Ci} / \mathrm{m}^{3}$. This nitrogen purge is also necessary for pressure control of the gloveboxes.

The primary and the secondary stripper systems are of identical design. They use the conventional tritium oxidation followed by water absorption method. The main components are heated catalyst beds and cooled zeolite beds. The purge stripper uses the same principle as the primary strippers, except that the catalyst is deposited directly on the zeolite and is operated at room temperature.

After saturation the zeolite beds are regenerated on-line, using the zeolite bed recovery system. The water is desorbed from the zeolite bed by heat and carried by hydrogen gas to a hot uranium bed. The uranium reduces the water and releases the elemental hydrogen isotopes. The tritium is later concentrated by an isotope separation system. The regenerated zeolite beds are reused. The spent uranium oxide beds are disposed of as a low level radioactive waste.

A schematic of the RTF tritium confinement system is shown in Figure 1. Detailed descriptions of the system components have been published elsewhere. ${ }^{3}$

\section{MATERIAL BALANCE OF THE IMPURITIES}

The main impurities of concern in the glovebox nitrogen atmosphere are tritium, water and oxygen. In the RTF their target levels are: tritium $\leq 0.1$ $\mathrm{Ci} / \mathrm{m}^{3}$, water $\leq 300 \mathrm{ppm}$ by volume, and oxygen $\leq 1 \%$ by volume. The source of tritium is from process leaks, diffusion through equipment walls, and offgassing from tritium contaminated parts and surfaces. The main source of oxygen is from air in-leakage, and water is from permeation through gloves.

The gloveboxes in the RTF are operated at a negative pressure of $124 \mathrm{~Pa}(0.5$ inch water) relative to the surrounding pressure. At an average leak rate of 1 $\mathrm{cc} / \mathrm{sec} / \mathrm{box}$ measured on helium, the oxygen in-leakage rate is calculated to be $0.3 \mathrm{~g}$-mole/box/day, or a total of $9 \mathrm{~g}$-mole/day for 30 gloveboxes. A very small portion of this oxygen is consumed in the oxidation of hydrogen isotopes. The rest is purged through the purge stripper. To purge $9 \mathrm{~g}$-moles of oxygen per day at a concentration of $1 \%$ by volume, the nitrogen purge rate required is $900 \mathrm{~g}$-mole/day $\left(0.5 \mathrm{ft}^{3} / \mathrm{min}\right)$. This required purge rate increases if the air in- 
leakage rate increases or if the oxygen level in the gloveboxes decreases. A small amount of tritium is purged with this stream. At a tritium concentration of $0.01 \mathrm{Ci} / \mathrm{m} 3$, the amount of tritium purged with the nitrogen at $900 \mathrm{~g}$-mole/day is $74 \mathrm{Ci} /$ year.

Permeation through the butyl rubber gloves is the main source of water. In the RTF there is a total of about 2,000 pairs of gloves. On the average about 1,000 of them are in use or not covered and permit the water in air to permeate. The total water permeation is calculated to be about $14 \mathrm{~g}$-mole/day. At this rate, the time to saturate a given zeolite bed is dependent on the moisture level permitted in the nitrogen, since the water capacity of zeolite decreases rapidly with the moisture level in the nitrogen. At moisture levels of $300,100,10$ and $5 \mathrm{ppm}$ by volume, the water capacity of zeolite are 17, 14, 6 and $4.5 \mathrm{wt} \%$, respectively. To remove $14 \mathrm{~g}$-moles of water per day the quantity of zeolite required is $1.5 \mathrm{~kg} /$ day if the moisture level in the glovebox is 300 $\mathrm{ppm}$, but the quantity increases to $4.2 \mathrm{~kg} /$ day if the moisture level is only 10 ppm. A $100-\mathrm{kg}$ size zeolite bed serving 15 gloveboxes can be effective for 130 days or 50 days dependent on whether the permitted moisture level is 300 $\mathrm{ppm}$ or $10 \mathrm{ppm}$. A material flow diagram of the glovebox stripper system is shown in Figure 2

The permitted moisture level in the glovebox is mostly determined by the tritium concentration in the moisture. For example, if the tritium concentration in the moisture increases from $0.01 \%$ to $1 \%$ by mole, the permitted moisture level decreases from $400 \mathrm{ppm}$ to $4 \mathrm{ppm}$, in order to prevent the tritium concentration in the nitrogen to exceed $0.1 \mathrm{Ci} / \mathrm{m}^{3}$. Note that $1 \mathrm{ppm} \mathrm{T}_{2} \mathrm{O}$ in one atmosphere nitrogen is $2.36 \mathrm{Ci} / \mathrm{m}^{3}$.

\section{PERFORMANCE AT NORMAL CONDITIONS}

The RTF stripper systems have been in operation for over a year, and have kept the tritium concentration in most of the gloveboxes at less than about $0.07 \mathrm{Ci} / \mathrm{m}^{3}$ compared with a target maximum of $0.1 \mathrm{Ci} / \mathrm{m}^{3}$. The exceptions are two gloveboxes which are frequently exposed to high levels of tritium contamination due to operation needs. After exposure to a high tritium concentration, the tritium concentration can stay in the range of 0.1 to 10 $\mathrm{Ci} / \mathrm{m}^{3}$ for weeks or even months. This will be discussed further in a later section.

The moisture level in the gloveboxes is normally at about $10 \mathrm{ppm}$, much lower than the target maximum of $300 \mathrm{ppm}$. This low moisture level helps to maintain the low tritium concentration, but also reduces the water capacity of the zeolite beds. 
The oxygen level in the gloveboxes is normally at about 7,000 ppm, versus the target maximum of $10,000 \mathrm{ppm}$. The purge rate has been in the range of 14 to 80 liters per minute $\left(0.5\right.$ to $\left.3 \mathrm{ft}^{3} / \mathrm{min}\right)$. At 80 liters per minute and $0.01 \mathrm{Ci} / \mathrm{m} 3$, the amount of tritium purged will be $1.2 \mathrm{Ci} /$ day.

The zeolite bed recovery system has regenerated several zeolite beds and permits them to be reused. The tritium concentration in the recovered isotope is normally about $0.03 \%$ by mole. On an estimated $14 \mathrm{~g}$-moles of water per day, the tritium recovered will be $242 \mathrm{Ci}$ /day.

\section{PERFORMANCE AT HIGH TRITIUM CONCENTRATIONS}

An accidental leak from the process introduced about 6 moles of tritium into one of the gloveboxes. The affected glovebox was immediately isolated from the other gloveboxes and switched to the secondary stripper system. The glovebox nitrogen was circulated through the stripper at nominal flow rate of $170 \mathrm{~m}^{3} / \mathrm{hr}\left(100 \mathrm{ft}^{3} / \mathrm{min}\right)$, which gave an average residence time of about 8 minutes. The change in tritium concentration in the glovebox was shown in Figure 3. The data indicate that the tritium concentration in the nitrogen decreased very rapidly at the beginning, from an estimated $8,000 \mathrm{Ci} / \mathrm{m}^{3}$ to 100 $\mathrm{Ci} / \mathrm{m}^{3}$ in about one hour. After that the decreasing rate became very slow and it took about 20 hours for the concentration to reach $20 \mathrm{Ci} / \mathrm{m}^{3}$, and 100 hours to reach $10 \mathrm{Ci} / \mathrm{m}^{3}$. In terms of percentage of recovery, $98.8 \%$ of the tritium in the nitrogen was recovered in the first hour. But after that, the concentration stayed at the $10 \mathrm{Ci} / \mathrm{m}^{3}$ for hundreds of hours. Decontamination activities were required to decrease glovebox concentration to the $1 \mathrm{Ci} / \mathrm{m}^{3}$ level. As will be discussed later, the long tail of concentration decay can be explained by incomplete mixing and tritium contamination inside the glovebox.

\section{STRIPPER PERFORMANCE MODELS}

The primary and secondary stripper systems in the RTF are of the same design. Each system consists of a preheater, a catalyst bed, a precooler, three zeolite beds, and two blowers. See Figure 4. The nitrogen flow rate is 2.8 $\mathrm{m}^{3} / \mathrm{min}$. The three zeolite beds are used one at a time. The other two beds are on standby while one of them can be under regeneration.

The electrically heated pre-heater increases the temperature of the incoming nitrogen from $25{ }^{\circ} \mathrm{C}$ to $400{ }^{\circ} \mathrm{C}$. The catalyst bed holds $0.14 \mathrm{~m}^{3}(130 \mathrm{~kg})$ of a palladium on alumina catalyst (Deoxo- ${ }^{\circledR}$ by Engelhard), which gives a residence time of 1.5 seconds. The temperature and residence time are more than sufficient to complete the oxidation of elemental hydrogen and methane. The water cooled cooler reduces the nitrogen temperature from 400 
${ }^{\circ} \mathrm{C}$ to less than $30^{\circ} \mathrm{C}$ before the gas enters the zeolite bed for water removal. The zeolite beds are filled with type $3 \mathrm{~A}$ zeolite which is used because it does not absorb carbon dioxide. Each bed holds $0.16 \mathrm{~m}^{3}(100 \mathrm{~kg})$ zeolite and gives about 3 seconds residence time. The water capacity of each zeolite bed is dependent on moisture levels of the glovebox nitrogen, from about $300 \mathrm{~g}$ mole at $10 \mathrm{ppm}$ moisture level to about $1,000 \mathrm{~g}$-mole at $300 \mathrm{ppm}$ moisture. The 3 zeolite beds are used one at a time. After saturation the zeolite beds are regenerated and reused.

In the most ideal case, the nitrogen in the glovebox is completely mixed; the catalyst bed converts all the hydrogen to water; and the zeolite bed absorbs the water to equilibrium. In such an ideal case, a material balance of tritium around the glovebox yields the following equation:

$$
\mathrm{dC} / \mathrm{dt}=\mathrm{F}^{*}\left(\mathrm{C}_{\mathrm{e}}-\mathrm{C}\right) / \mathrm{V}
$$

where $\quad C=$ tritium concentration in glovebox

$\mathrm{t}=$ time

$F=$ flow rate

$\mathrm{C}_{\mathrm{e}}=$ equilibrium tritium concentration at zeolite bed exit $\mathrm{V}=$ glovebox volume

Integration of equation (1) yields:

$$
\left(C-C_{e}\right) /\left(C_{0}-C_{e}\right)=\exp \left(-F / V^{*} t\right)
$$

where $\quad \mathrm{C}_{0}=$ tritium concentration in glovebox at time 0 .

Equation (2) can be used to calculate the ideal tritium concentration as a function of time after a given amount of tritium is introduced in the glovebox. However, in practice, the ideal conditions are seldom met, and the actual tritium decreasing rate is slower than the ideal rate. The two most likely factors which deviate from being ideal are the mixing inside the glovebox and the adsorption and off-gassing of tritium by the surfaces inside the glovebox. If mixing in the glovebox is incomplete then some of the gas is short circuited back to the stripper before it has a chance to mix with the gas in the glovebox. If the surfaces of equipment inside the glovebox are contaminated with the high concentration of tritium at the beginning when the tritium is introduced, then the surface tritium will later be released back to the glovebox as the tritium concentration decreases. To include these two conditions, the material balance equation (1) is modified and written as follows:

$$
\mathrm{dC} / \mathrm{dt}=\left(\mathrm{F}^{*}\left(\mathrm{C}_{\mathrm{e}}-\partial^{*} \mathrm{C}\right) / \mathrm{V}+\mathrm{A}^{*} \mathrm{D}^{*}\left(\mathrm{C}_{\mathrm{s}}-\mathrm{C}\right)^{0.5}\right) / \mathrm{V}
$$

where the new variables 
$\partial=$ mixing factor, value for 0 to 1,1 is complete mixing

$\mathrm{A}=$ surface area inside glovebox that adsorbs and release tritium

$\mathrm{D}=$ tritium releasing coefficient, units in length/time

$\mathrm{C}_{\mathrm{s}}=$ average tritium concentration in surface layer

$\mathrm{C}=$ tritium concentration measured in the glovebox.

Material balance on the surface layer may be written as:

$$
\mathrm{dC}_{\mathrm{s}} / \mathrm{dt}=\mathrm{A}^{*} \mathrm{D}^{*}\left(\mathrm{C}_{\mathrm{s}}-\mathrm{C}\right)^{0.5} / \mathrm{V}_{\mathrm{s}}
$$

where $\quad V_{S}=$ volume of surface layer.

Solving equation (3) and (4) simultaneously will give the tritium concentration as a function of time after a tritium release in a glovebox, provided that the necessary parameters are known. However, the values for $\partial, A, D, C_{s o}$ (=surface layer tritium concentration at time 0 ) and $V_{s}$, are not known. But one can assign some approximate values for them and compare the calculated results with the data and with the ideal model. The exercise that follows will show that the modified model can describes the data much better than the ideal model. The given conditions are as follows:

Nitrogen flow rate, $\mathrm{F}=170 \mathrm{~m}^{3} / \mathrm{hr}$

Residence time in glovebox, $\mathrm{V} / \mathrm{F}=0.14 \mathrm{hr}$

Tritium concentration in glovebox at time $0, \mathrm{C}_{0}=8,000 \mathrm{Ci} / \mathrm{m}^{3}$

(estimated since the concentration is outside instrument range)

Equilibrium tritium in nitrogen at zeolite bed exit, $\mathrm{C}_{\mathrm{e}}=0.015 \mathrm{Ci} / \mathrm{m}^{3}$.

The above values are used in the ideal model (equation (2)) to calculate the tritium concentration as a function of time. Compared to the data, the calculated concentration decreases at a much fasted rate than the data. In two hours, the model has decreased to the equilibrium level of $0.015 \mathrm{Ci} / \mathrm{m}^{3}$, but the data is still at about $70 \mathrm{Ci} / \mathrm{m}^{3}$.

To use the modified model (equations (3) and (4)), the following values are assigned to the parameters:

Mixing factor, $\partial=0.6$

Surface area inside glovebox, $A=65750 \mathrm{~m}^{2}$ (1,000 times the glovebox wall)

Tritium releasing coefficient, $D=10^{-6} \mathrm{~m} / \mathrm{hr}$

Tritium concentration in surface layer at time $0, \mathrm{C}_{\mathrm{so}}=1.6 \mathrm{E} 9 \mathrm{Ci} / \mathrm{m}^{3}$ (same as liquid TDO)

Volume of surface layer, $V_{s}=1 E-4 \mathrm{~m}^{3}$ (5-molecule deep, 1 molecule $=3 \AA$ ) (tritium in the surface layer at time $0=C_{\text {so }}{ }^{*} V_{s}=17 \mathrm{~g}$ ). 
Equations (1) and (2) are numerically integrated. The results are shown in Figure 5 and are compared with the ideal model results and the data. The comparison indicates that the modified model represents the data much better than the ideal model, supporting the idea that incomplete mixing and contamination are causing the slow decrease of tritium concentration in the glovebox.

\section{DISCUSSION AND CONCLUSIONS}

The RTF glovebox-stripper system meets the objectives of reducing tritium release to the environment and worker protection. The tritium level in the nitrogen gloveboxes is normally kept at less than $0.1 \mathrm{Ci} / \mathrm{m}^{3}$. When a large quantity of tritium is introduced in a glovebox increasing the tritium concentration to a level much higher than $100 \mathrm{Ci} / \mathrm{m}^{3}$, the stripper can recover more than $98 \%$ of the tritium in the gas phase in about 1 hour $(\sim 8$ residence time). But the concentration can stay at about $10 \mathrm{Ci} / \mathrm{m}^{3}$ for weeks. Decontamination of the glovebox surfaces is required before the tritium concentration can be reduced to a level less than $1 \mathrm{Ci} / \mathrm{m}^{3}$.

The ideal model, which assumes complete mixing and no contamination inside the glovebox, is too optimistic and predicts a tritium decreasing rate much faster than the data. A modified model, which includes the effects of incomplete mixing and surface contamination, can simulate the data much better than the ideal model. The data and the analysis demonstrated the importance of the mixing factor and the contamination factor in tritium stripper system design and operation.

\section{REFERENCES}

1. M. S. Ortman, L. K. Heung, A. Nobile, and R. L. Rabun III, "Tritium Processing At The Savannah River Site: Present and Future", J. Vac. Sci. Technol A 8 (3), p2881, May/Jun, 1990.

2. T. Motyka, "The Replacement Tritium Facility", Fusion Technology, Vol. 21, Mar, 1992.

3. L. K. Heung, et al, "Tritium Confinement In A New Tritium Processing Facility At The Savannah River Site", Fusion Technology, Vol. 21, p594, Mar, 1992. 
Figure 1 Schematic Of The RTF Tritium Confinement System

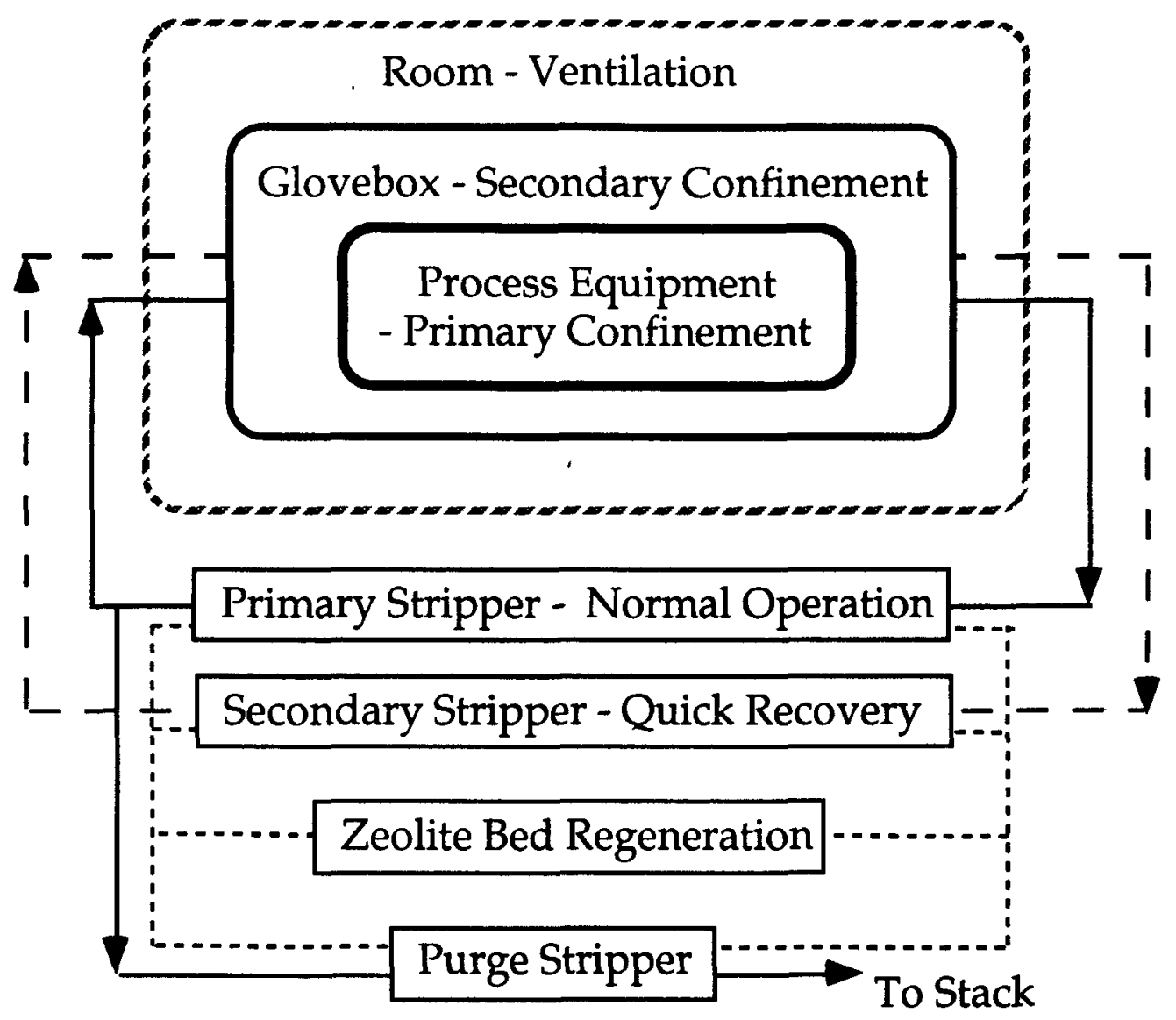


Figure 2 Glovebox-Stripper Material Flow Diagram

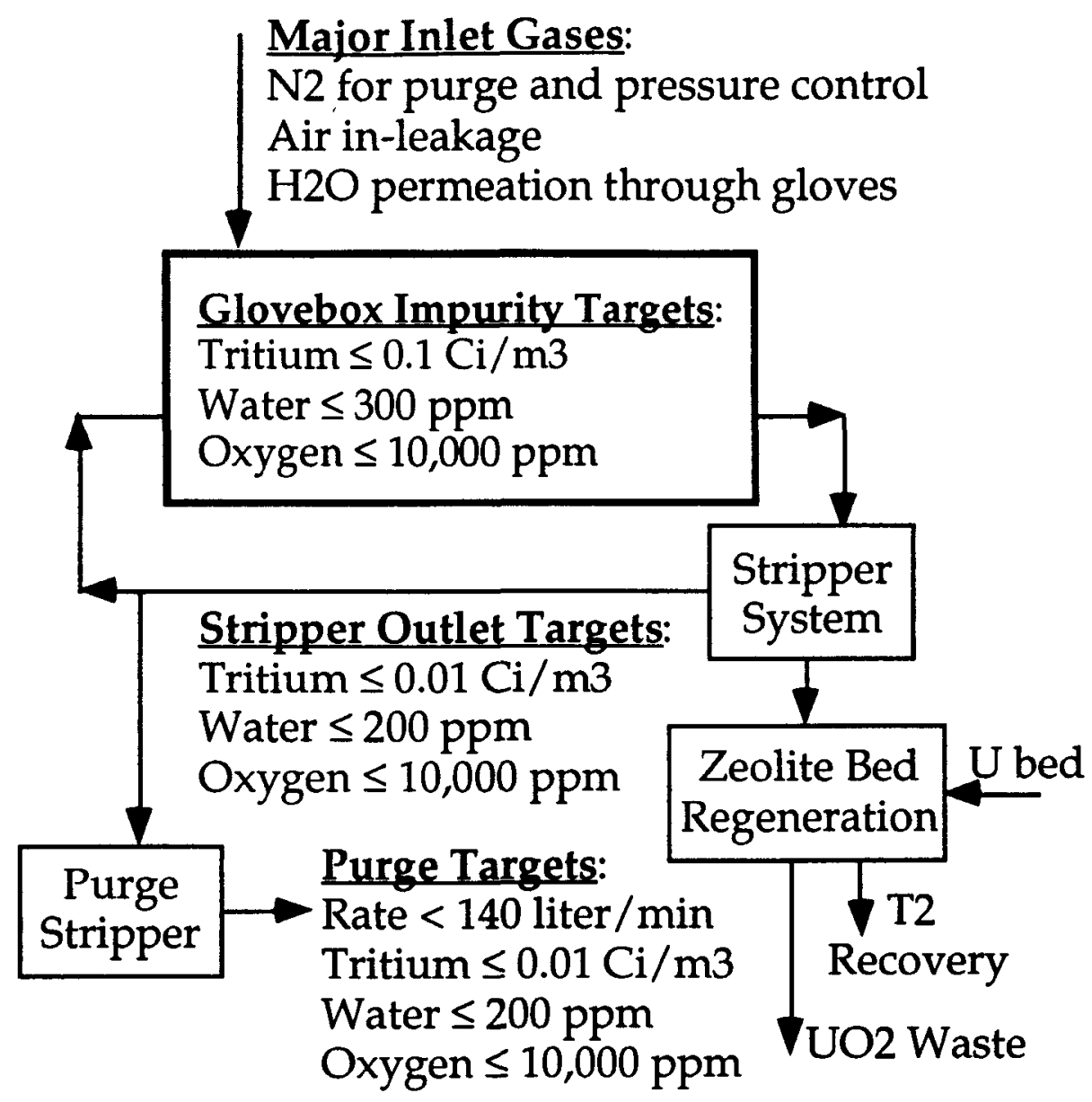


Figure 3 Glovebox-Stripper Performance Data

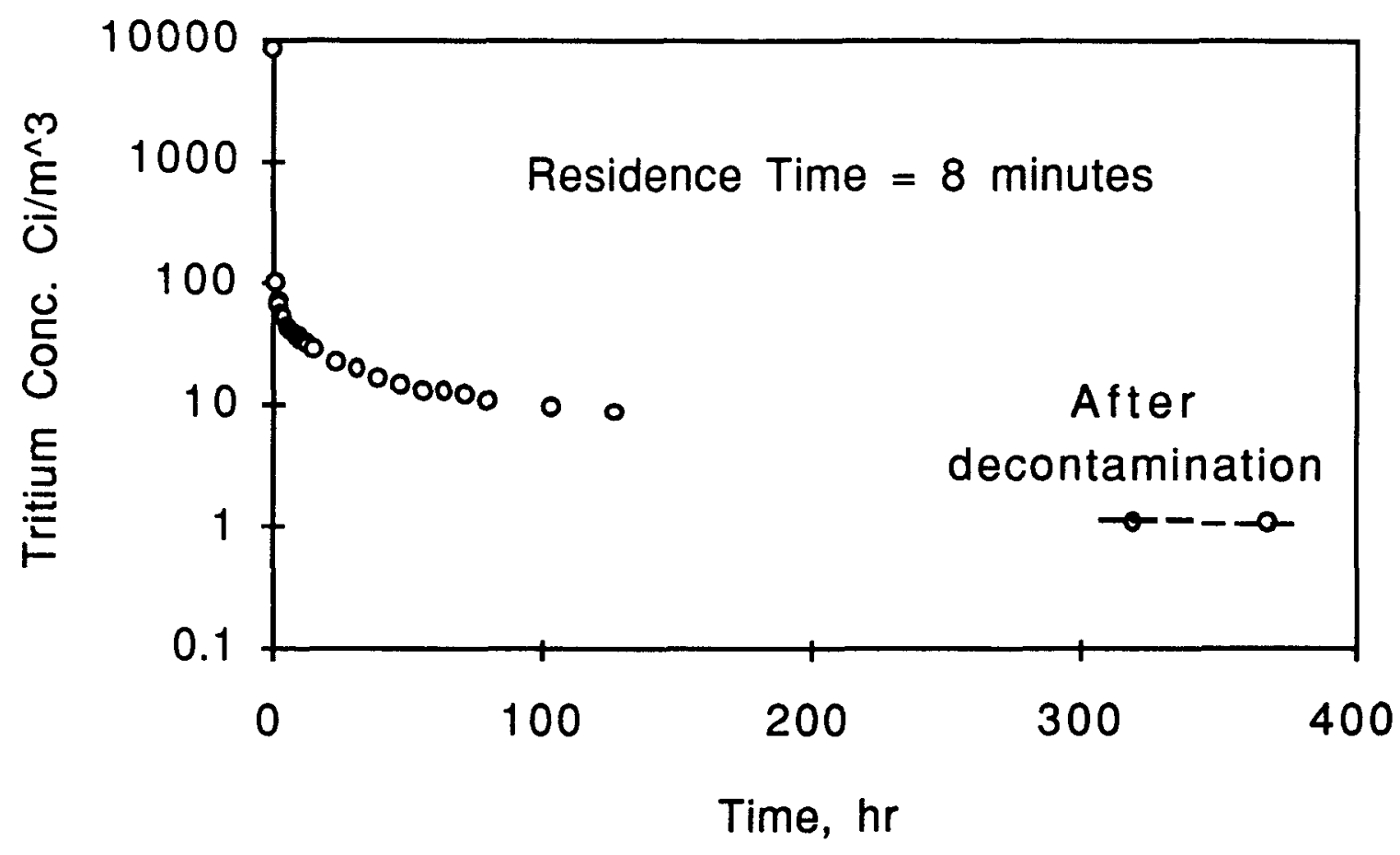


Figure 4 Flow Diagram Of The Primary Stripper

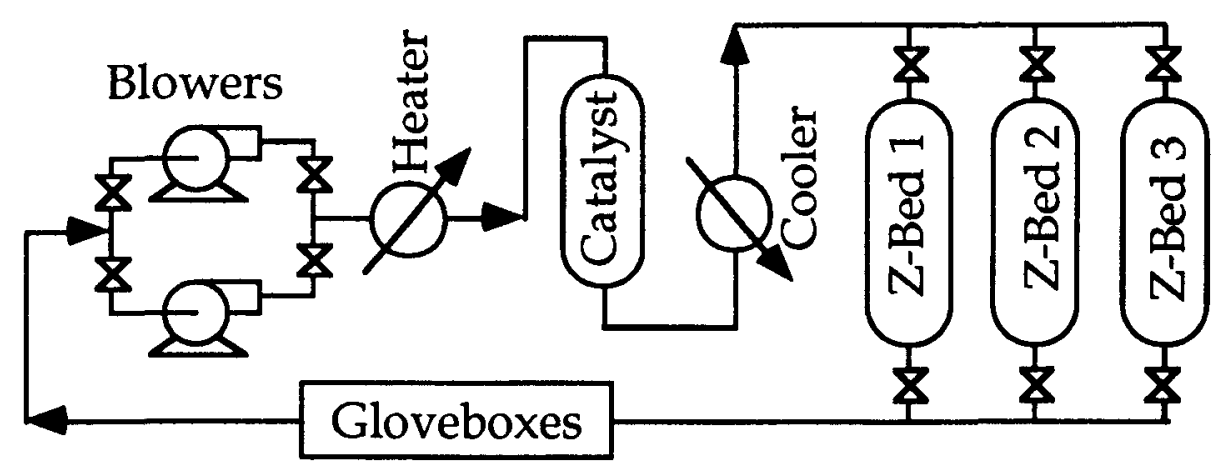


Figure 5 Glovebox-Stripper Data Compared To Models

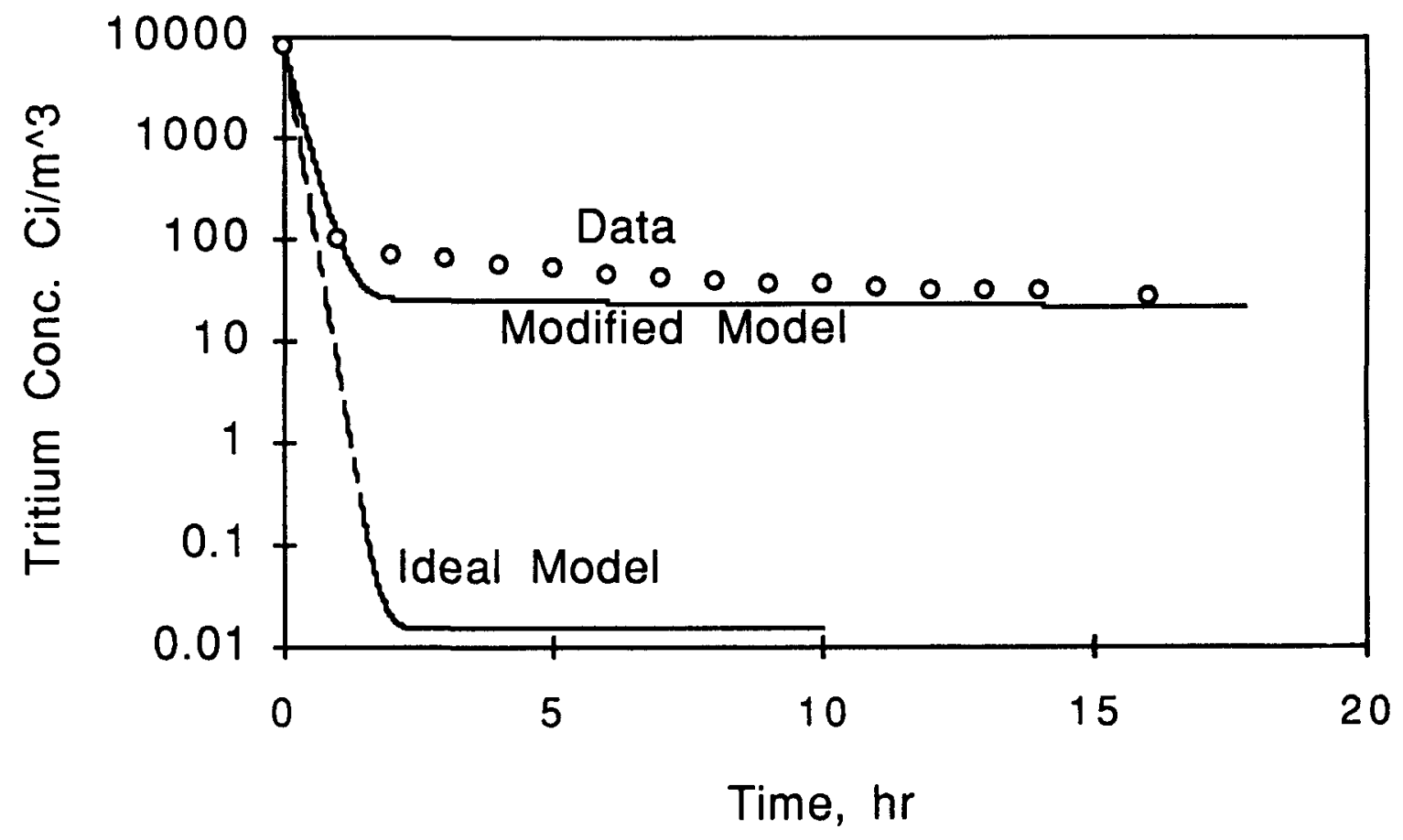

